\title{
Exploring children's discourses of writing
}

\section{Andrew Lombirth}

Professor of Education, University of Greenwich

\section{Abstract}

This article reports on a study which was part of a two year writing project undertaken by a University in South East England with 17 primary schools. A survey sought the views of up to 565 children on the subject of writing. The analysis utilises Ivanič's (2004) discourses of writing framework as a heuristic and so provides a unique lens for a new understanding of children's ideological perspectives on writing and learning how to write. This study shows the development of learned or acquired skills and compliance discourses by the participating children within which accuracy and correctness overrides many other considerations for the use of the written word.

\section{Keywords}

writing, discourse, language, ideology, learning

\section{Introduction}

The article explores the discourses of writing articulated by a sample of children from seventeen primary schools in South East England on a two-year project. The research identifies the 'constellations of beliefs' (Ivanic 2004) about writing and learning to write represented by the children's responses to a survey. The analysis draws on the work of Ivanic (2004) and her 'Discourses of Writing' framework, which helps interpret what the children in this study appeared to conceive to be socially accepted values and beliefs about writing and learning to write in their schools. In doing so, I introduce a new discourse, the 'compliance discourse', as an extension of Ivanic's 'skills discourse' to help further understand the children's beliefs about writing. Asking children about writing enabled teachers to assess their pupils' development as writers very differently from their usual assessment practices; they were able to assess the children's development as young writers as being formed socially and ideologically. Many of the teachers of the children were alarmed by what the children 
articulated about writing and recognised the discourses being used. It is hoped that the content of this article will help practitioners, education academics and policy-makers recognise the specific sets of beliefs and values that can be held by pupils learning to write in schools and to consider if these perspectives are desirable for developing fully independent and assured writers. The research suggests the value of more regular and direct exchanges of ideas about learning to be literate between children and teachers and that the analysis of children's discourses about writing should form part of assessment processes.

\section{Discourses}

Fairclough (2001) contends that language is part of society and that linguistic phenomena are social phenomena. His view is that 'when people speak or listen or write or read, they do so in ways which are determined socially and have social effects' (p.19). Gee (2001:1) has defined discourse as:

A socially accepted association among ways of using language, of thinking, and of acting that can be used to identify oneself as a member of a socially meaningful group or "social network"

Gee 2001

For Gee (2001) discourses are 'ideological'. They will contain values and viewpoints which participants in the discourse must be able to enact to belong to the discourse community. Discourses are resistant to internal criticism; indeed, uttering viewpoints which undermine the discourse label the speaker as being outside the discourse. Furthermore, discourses, as Gee explains, concern themselves with certain objects and will hold specific viewpoints and concepts and values at the expense of others. Finally, discourses are part of the structures and processes that distribute social power. Being in possession and control of specific discourses can lead to social advantages. One comes by discourses that one can control, Gee argues, through either 'acquisition' or 'learning'. One can acquire a discourse subconsciously 'by exposure to models and a process of trial and error without formal teaching' (Gee 2001:3). Discourses are acquired when one knows one needs to acquire them. On the other hand, learning to have control over discourses 'involves conscious knowledge gained through teaching' (Gee 2001:3).

As Fairclough (2001:2) argues, 'Ideologies are closely linked to power'. The relationship of discourses to a totality of belief about reality is the notion of hegemony. Williams (1976) defined hegemony as a whole body of practices and expectations; a set of meanings and values which in practice appear reciprocally confirming. Following Gramsci, Williams argued that hegemony is something beyond separate discourses or ideology, something truly total (Apple 2004). This totality of belief that forms consciousness and a reality is incorporated by discourses, some of which we learn and acquire during the process of schooling. 
Discourses of writing and learning to write, following this argument, contribute to the incorporation of a hegemony, 'a saturation of consciousness' (Apple 2004:4) and so, one can argue, these discourses of writing need to be understood to recognise how they contribute to learners' conceptualisation of their world and their place within it. How people locate themselves in relation to certain discourses reflects the socially sanctioned dominance of certain ideologies and subjugation of others. Discourses too vary in their authority (Gavey 1989: 464). A discourse can be contested by others. At one particular time one discourse can seem 'natural' while another struggles to find expression in the way experience is described.

It becomes crucial, I want to argue, for teachers to be cognisant of how individual pupils and groups of individual pupils perceive their place within the firmament of linguistic belief and practice.

\section{Ivanic's discourses of writing framework}

Ivanic (2004) defines discourses of writing as:

constellations of beliefs about writing, beliefs about learning to write, ways of talking about writing, and the sorts of approaches to teaching and assessment which are likely to be associated with these beliefs (p.224)

Ivanic (2004) states that participating within the discourse identifies the participant as belonging to the group who speak, write and act within the same discourse. However, she makes the point that discourses are not always homogeneous, but can be hybrid and draw on two or more other discourses. We as humans, Ivanic argues, are not completely determined by social discourses. We have the agency to enable us to recombine and transform the discourses which are available to us. Nonetheless, Ivanic recognises that individual discourses can be identified from the behaviour of individuals and groups of individuals and so she produced her discourses of writing framework in order to make these classifications. Ivanic describes six discourses of writing:

- Skills

- Creativity

- Process

- Genre

- Social practice

- Social Political

This article focuses on two discourses described by Ivanic as these were identified as recurring themes that emerged from the data: skills and creativity discourses. To define the others briefly: Ivanic's process discourse refers to a belief that writing consists of composing processes in the writer's mind and their realisation in the activity. Genre discourse describes writing as a set of 
text-types shaped by social context. Social practices discourse conceives writing as being purpose driven communication within a social context and a $\mathrm{so}^{-}$ cial and political discourse is the belief that writing is a socially constructed practice and has consequences for identity and is open to contestation and change. The children's responses in this study were not interpreted in the main as belonging to these four last discourses. This would not come as a surprise to Ivanic. She writes:

\begin{abstract}
Actual texts, actual curricula, people writing or talking about literacy, and observable pedagogic practices may instantiate one of these discourses, or may be hybrid instantiations of two or more of them
\end{abstract}

(Ivanic 2004:240).

She goes on to say how teachers need to be aware of how pressures on them to undertake certain forms of pedagogy may 'privilege one discourse at the expense of others' (2004:241) and so it is conceivable that not all the discourses are seen to be prevalent.

A skills discourse of writing works around a belief that writing consists of the application of a set of linguistic rules and patterns for sound-symbol relationships and sentence construction. Ivanic argues that the more extreme aspects of this discourse conceptualise writing as 'unitary, context-free' (p.227) so that the same linguistic rules can be applied to all types of writing. These beliefs produce a 'skills' based pedagogy which will focus upon correct handwriting, spelling, punctuation and sentence structure. One can recognise the discourse in references to 'skills', 'spelling', 'punctuation' and 'grammar' and in references to expressions such as 'correct', 'accurate', 'proper', 'learners' 'must/should', in the teaching of explicit and prescriptive rules. Furthermore, accuracy is emphasised in approaches to assessment. A skills discourse concentrates on learners' attaining technical accuracy in their writing which is demonstrated by presentation of finished transcriptions of texts that adhere to the appropriate linguistic rules

A creativity discourse, according to Ivanic (2004), highlights the quality of the content and style of a piece of writing. The meaning of the writing is celebrated over linguistic accuracy and presentation of the transcription. This discourse includes a strong belief in the value of writing as a creative process for the writer in its own right. Pedagogy is influenced by a notion that one learns to write by writing. To progress as a writer one must write a good deal (Britton 1970, Dixon 1967, Elbow 1973, Graves 1983). Developing writers need to be motivated to write by inspiring subjects which are relevant and interesting to the writer. Writing is assessed by the quality of its content and style as least as much as its accuracy. The discourse is recognised by expressions such as 'creative writing', 'the writer's voice', 'story', 'interesting content'. Ivanic also includes expressions such as 'good vocabulary/words' to be part of the creative discourse. In the analysis section I later introduce a caveat to the inclusion of this vocabulary in the creative discourse. 


\section{Children's views of writing}

Earlier work that specially elicits the views of primary aged children on writing have not analysed the data using discourse as a theoretical lens (NWP 1990, Wray 1993, Grainger, Goouch and Lambirth 2003, 2005). In all these studies the children saw writing at school as being about product rather than process. In Grainger et al.'s (2005) study, teachers described what they were doing and what the children were doing as 'playing the game called writing' - working to a formula to produce writing that would be graded highest by assessment measures. Despite the teachers' views, Wray (1993) argued that teachers and researchers may be too hasty to conclude that the teaching produced the views of the children. He argued that the children in his study mentioned more readily the aspects which were particularly bothering them at the time. As an aspect of writing was mastered by the children, they mentioned it less. Yet, even though it may be true that children tend to talk about aspects of writing that are of concern to them, across the three studies the transcriptional and technical features were a consistent part of their understanding of what learning to write was all about. Exploring what children say, utilising Ivanič's (2004) framework as a heuristic, provides a unique lens that seeks to reveal an ideological thread of the analysis.

This study will not be the first that has utilised Ivanic's framework; but previous studies (Lundgren 2013, Baker 2011, McCarthey, Woodard and Kang 2013) did not make the writing discourses of primary school aged children (4-11 years old) their focus. Children's views were the object of this study. Analysing these views was a way to try and understand children's growing deep and ideological affiliations with writing in society.

\section{Context and design of the project}

The study was part of a two year writing project undertaken by a University in South East England and 17 primary schools in the surrounding area between 2013 and 2015. The project was funded by the participating cluster of schools.

The writing project began by collecting information about how writing and learning to write was perceived by children in the schools from Reception (age 4-5) to Year 6 (age 11). The teachers had never undertaken a survey of the children's views about writing before.

In recent school inspections by the UK Office for Standards in Education (Ofsted) twelve of the schools in the study had been graded 'good', three were considered 'outstanding' and two had been graded as 'requiring improvement'. All the schools had children attending who were from mainly white British backgrounds. Only four of the schools had above average numbers of children eligible for free school meals. a statistic often used in the UK as an indicator of deprivation.

The survey instrument is one that had been developed over a number of years on similar projects (for example Grainger, Goouch and Lambirth 2003, 2005, 
Bearne et al., 2007) which had sought the views of children on the subject of writing. The survey produced both quantitative and qualitative data.

There were 18 questions on both versions of the questionnaire with a mixture of open and closed questions. The teachers on the project were interested to know if the children enjoyed writing and their preferences for writing environments and stimulation. The group also agreed to ask the children about their perception of their teachers as writers and if they thought their teachers wrote much at home. The teachers also wanted to make links with drawing and asked them if they drew at home and if they wrote at home.

The teachers became most interested in the questions which sought the children's perceptions of writing and their perspectives on writing in general. This article focuses on three of these questions:

Is there someone in your class who you think is a good writer? If so, please tell us why you think they are a good writer.

\section{Can you remember a piece of writing you did when you were younger that you were particularly proud of? If so, what was good about it?}

What advice would you give to children a year younger than you to belp them with learning to write?

\section{The procedure}

Ethical procedures undertaken in this study were approved by the University ethics committee. Six children (3 girls, 3 boys) from the top and bottom of the register alphabetically were selected from each class in the seventeen participating schools. Older and more experienced readers and writers completed the survey on Survey Monkey during a convenient time during the school day. Younger and less experienced readers and writers were provided with an adult reader and a scribe. The power differentials in schools create methodological problems about seeking children's opinions within the context of the school. However, the power imbalance was integral to the approach taken (Morrow 2001) as the research team sought the views of children about writing within the school environment. In these circumstances reflexivity needed to be central to the research process with children, where researchers critically reflect on their role and their assumptions (Davis 1998). The questions that were asked had been devised and agreed by the professionals who worked most closely with the children. They had developed a professional rapport and were best placed to judge if the children could and would answer the questions the team wanted to ask. With the younger children the adults articulated the questions in ways they believed children would best be able to answer them. 
The children who undertook the survey did not choose to answer all the questions. For the three questions discussed in this article, the number of respondents ranged from 492 to 565, with 20\% not answering the question asking them for advice for their peers on teaching writing. As will be shown, most of the children's written answers were brief. The examples shown in this article were unedited in length, although spellings were corrected for the sake of ease of reading.

\section{Data Analysis}

The purpose of the survey was to gather broad information on children's attitudes and perceptions of writing in the schools involved in the writing development project.

The qualitative data were analysed thematically. The analysis was completed by two university staff members, one of whom had no involvement with the project but had expertise in teaching English; the other was the writer of this article. Both researchers worked separately at first, using an inductive process of narrowing data into themes (Creswell 2012) based on Ivanic's framework. All the written answers from each school within the individual projects were studied together question by question and each answer was categorised thematically. When children solely mentioned one particular aspect of writing or when an aspect of writing dominated their answer, this was coded accordingly. After this initial analysis, the researchers met to discuss the themes that had emerged and agreement was sought over the themes from the individual analysis. Those answers which did not fit a theme were separated. The number of answers in one particular category was counted and converted into percentages. The initial results of the analysis were taken to the teacher meetings for further scrutiny and cross-checking of the themes with the teachers involved.

In addition to Ivanic's skill discourse and creativity discourse, another discourse was identified which was related to and overlaps the skills discourse. It describes children's beliefs about the necessary efforts needed to produce writing which will please the adults from whom the writing tasks were given. I want to call this a compliance discourse. It indicates the children's belief in the importance of approbation from the teacher as being central to the satisfactions of completing writing that is correct, accurate and proper and has been forged through hard work, all of which draws praise from adults around them. It is detached from the more aesthetic and creative satisfactions of writing and from the meaningful communicative purposes of writing. Instead, writing is perceived as a school exercise that can be well done and worthy of praise. The children's work is objectified as the children learn to receive praise for a 'thing' alienated from any meaningful human communicative activity. The discourse is manifested in words such as 'practise', 'hard work', 'impress', 'effort'. It was sometimes difficult to discern between comments we thought belonged to a compliance discourse and those that belonged to a skills discourse - indeed it is clear from the data that there is sometimes overlap. 
In the survey it became evident that when children referred to good vocabulary or the use of specific types of words - adjectives for example - they used them as part of what I want to argue was a skills discourse instead of a creativity discourse within which Ivanic classifies such references. They rarely used them to illustrate how these types of words contributed to meaning or the creativity of the piece. The research team felt that the children were referring to the use of these words as a way to contribute to the accuracy and presentation of the piece - the writing was still being objectified. Indeed, the teachers on the project agreed with this analysis and attributed the children's comments to their teaching which endeavoured to ensure positive assessment results. Furthermore, the children referred to aspects of compositional qualities of writing as part of a formulaic approach to their work which appeared to suggest a discourse linked with presentation and correctness. This skills discourse is illustrated by children's phrases such as 'good sentence openers', 'loads of connectives and adjectives' 'Capital letters, verbs and nouns'.

From the three questions discussed here, four main themes emerged:

- Skills Discourse

- Creativity Discourse

- A Compliance discourse - the need for hard work; concentration and listening to the teacher

- Other: no answers, unreadable or inappropriate answers

\section{Results}

Over $90 \%$ of the children stated in the survey that they enjoyed writing. The majority of children wrote and drew at home. Most children thought that their teachers did write, but they believed that teachers almost exclusively wrote for professional teacher-led purposes - marking, report-writing and producing models of types of texts which the children were asked to write in class.

In the boxes below I provide some examples of comments which were categorised into discourses of writing. In most cases the children's comments were short. The nature of these responses was not confined to particular schools or year groups.

Box 1 Question A: Is there someone in your class who you think is a good writer? If so, please tell us why you think they are a good writer.

\begin{tabular}{lllll}
\hline Responses & Skills Discourse & Creativity Discourse & Compliance Discourse & Others \\
\hline 557 & $54.7 \%$ & $17 \%$ & $22.6 \%$ & $5.7 \%$ \\
\hline
\end{tabular}




\section{Box 2 Skills Discourse}

1 I think they are a good writer because they always do the right punctuation

2 Neat handwriting, good sentence openers

3 They think of really good adjectives and adverbs and they make their punctuation and words interesting,

4 Adventurous middle

5 They always follow all the main rules in writing

6 They have really neat handwriting and they remember to add capital letters and full stops and they have interesting sentences

7 Their neat hand writing with a pen

8 She uses really good adjectives in her stories and puts her writing in really organised paragraphs

9 I think they are a good writer because they always do the right punctuation and is always doing detailed writing

10 Because they do brilliant pieces of work and show the best of their ability

11 They have good punctuation, good verbs

12 Descriptive text, capital letters, adjectives, verbs, punctuation and different types of starting your sentence

\section{Box 3 Creativity Discourse}

1 Their imagination, their creativity

2 Because I read her stories and the stories she writes are really good

3 They are always imaginative

4 I think the fact that they have a great imagination can make them a brilliant writer and they also use true facts to make great stories

5 Someone that can draw you in and make you want to read more.

6 When I see him reading a book I see him reading it again and again. So do I. I know how much books mean to me and him. He loves reading books once you have got a book he is stuck to it. He literally cannot even put a book down until he has read it about 5 times

7 I think the fact that they read lots of books and watch loads of TV and they are very imaginative makes them a good writer and they are also can read really well 


\section{Box 4 Compliance Discourse}

1 It makes them a good writer because they work hard and they get on with what they're supposed to do and they listen to the questions they have to do

2 They always get a thesaurus to get a better word to impress the teacher

3 They are on the second to last table and are sometimes better than me and I'm on the top table!

4 They use the VCOP Board

5 Because they always get there spellings correct however they always do capital letters and full stops. Their handwriting is neat and they always get good marks in their books. I get good marks in my book as well but sometime get something like try harder next time and be more specific and I do that in my writing

6 That they practise all the time

Box 5 Question B: Can you remember a piece of writing you did when you were younger that you were particularly proud of? What was good about it?

\begin{tabular}{llll}
\hline Responses & Skills Discourse & Creativity Discourse & Compliance Discourse \\
\hline 565 & $41.4 \%$ & $16.4 \%$ & 42.2 \\
\hline
\end{tabular}

\section{Box 6 Skills Discourse:}

1 It had loads of connectives and good adjectives

2 Because it was neat and tidy

3 Because I did it neat

4 I used high level words

5 Everything. Punctuation, writing and vocabulary

6 It was very, very neat

7 That I moved up some sublevels or I used my targets all right

8 I used speech marks and explanation marks!

9 It made me proud because my writing was neater then before by a lot and it was a lot better than my piece of writing before that

10 It made me proud of it because I hadn't worked that fast before and how much I did and how neat it was 


\section{Box 7 Creativity Discourse}

1 It made me think about me when I'm in my bed, when I see stuff in my bed

2 It was full of adventures

3 It was inspired by rap as well as religion

4 It had laughter and action and good words

5 The limitless ideas we were allowed to include

6 It had very preposterous vocabulary

7 That it had lots of information and it was quite dark

\section{Box 8 Compliance Discourse}

1 Because the teacher thought it was good so that made me think it was good

2 I was proud of it because I felt that I worked hard and did my best.

3 Because I put so much effort in

4 Having good marks

5 I got to see the head teacher and got two stickers for it

6 My teacher liked it

7 It was good because my teacher liked it

8 I used lots of good description and tried to use a wide range of sentence

structure- I succeeded in that(I think)-also my teacher graded it as a level 6

Box 9 Question C: What advice would you give to children a year younger than you to help them with learning to write?

\begin{tabular}{lllll}
\hline Responses & Skills discourse & Creativity discourse & Compliancediscourse & Others \\
\hline 492 & $60.1 \%$ & $7.7 \%$ & $18 \%$ & $14.2 \%$ \\
\hline
\end{tabular}

\section{Box 10 Skills Discourse:}

1 Try really hard and keep going through the levels

2 You need neat handwriting. Different connectives instead of "and" all the time

3 I would say remember to do all your success criteria

4 Use more VCOP!

5 Capital letters, nouns, adjectives and adverbs

6 Check your spellings. Do as many complex sentences as possible

7 Remember capital letters and full stops and include nouns, adjectives, verbs, subordinate clauses, articles, and try to make your writing neater 


\section{Box 11 Creativity Discourse:}

1 Try to be creative as possible and read lots of books

2 Use imaginative ideas and sometimes some humour and some sadness

3 Write made up stories and enjoy it. Think of good stuff like birds, trucks, cars, trains and unicorns.

4 Stories are about imagination

\section{Box 12 Compliance Discourse}

1 Use a wide range of vocabulary the teachers love it!

2 Try really hard and keep going through the levels using lots of description

3 I would give them advice to listen, to concentrate and to get on with it

4 Do your best and try and reach your target set by your teacher

5 Listen to the teachers and follow instructions

\section{Discussion and Conclusions}

\section{Box 1 Question A: Skills Discourse: being a writing technician}

In answers to all the questions children shared a common language in describing the quality of the writing: a sentence has an 'opener' and writing is good if one can call it 'adventurous'. The comments refer to attributes of the writing which bring value, like 'interest' (Question A6). Yet the interest was within the context of a sentence, arguably a technical interest rather than aesthetic interest. The children were adept at using the names for the parts of speech and were clearly impressed by how the children use adjectives and adverbs. However, there was little emphasis on how the use of these words contributed to the quality of the meaning-making and on the quality of individual pieces of work. This is not to deny the children's achievement of utilising these skills so well or to undervalue the importance of children's engaging in this aspect of writing. Yet the focus was upon the mechanism of the writing produced. Compositional aspects like the use of verbs and adjectives appeared to the teachers and university team to be praised by the children for their correctness and their place within a formula. Overall the presentation of the writing seemed to be of the greatest importance to these young writers.

Research that has studied effective teaching of writing in schools has shown that effective literacy teachers balance the technical and compositional aspects of learning to write in their teaching (Dombey 2013). They integrate the technical and compositional aspects of learning to write. Attention to technical features is contextualized in the process of teaching about purposeful writing (Knapp et al. 1995). This is borne out by the findings of Medwell et al. (1998) 
in England, Wilkinson and Townsend (2000) in New Zealand and Louden et al. (2010) in Australia. As a result of hearing children's perspectives, the teachers on this writing project were keen to introduce more of a balance in their teaching. Indeed, Ivanic (2004) in her work advocates a comprehensive view of writing which engages interest and value in a range of aspects of writing, including the technical and skills based.

The young learners in this study appear to see themselves as writing technicians who are beginning to understand the means to efficiently execute the task they are given. This is no mean feat, but from what they have articulated, writing is seen less as an exercise of artistic, creative and intellectual endeavour and much more as a technical task. The application of rules for writing (Question A5) can ensure an efficient way of accomplishing the task.

\section{Creative Discourse}

The respondents attribute much of the creativity to their peers' abilities - they are imaginative and they are creative (Question A1, 3, 4). The writers have these traits anyway, and this is the main source of the writer's ability to produce interesting texts. The quality of the text and the child's imaginative 'self' are linked. The skills and technical abilities of their peers or the correct formula being followed are not the first aspects of what makes a good writer. The text reflects the subjectivity of the writer. Through the creative manipulation of language, readers of their work can be 'drawn in' to the worlds the writer creates. In Question A5 the ability of the writer to creatively engage the reader is also emphasised, encouraging the creation of a secondary world (Benton and Fox 1989) for readers to 'enter'. This shows how the writer of this response to the question is aware of the imaginative process. The experience of reading the written words and seeing stories in filmic modes is seen as important for providing creative models with which the writer can create their own meaningful and rich texts.

\section{Compliance Discourse}

The answers which the research team are calling part of a 'compliance discourse' emphasise the work-person-like attitude, and show the children's determination to achieve the task which has been set them. Three out of the six exemplar answers to Question A $(3,4,5)$ demonstrate a 'task execution' (Berreiter and Scardamalia 1993) approach to the writing which will bring forth outcomes, in this case, unrelated to the meaning, purpose or content of the writing itself. The children here measure the success of the writing by the level and nature of the approbation from teachers the work receives - this is often judged by the marks they receive. The labour and the commitment of the writer to do as 'they're supposed to do' is reason enough to consider the children good writers.

\section{Question B: Skills Discourse}

Once again the skills based and technical aspects of the writing with which the children were pleased defined the quality in many of their answers. Some of 
the comments show the children's awareness of their own development based around levels, sub-levels and targets (A6) and a hierarchy of words. As in an earlier study (Grainger, Goouch and Lambirth, 2003), the children and the teachers are 'playing the game called writing'. The children are engaging in the production of writing in a formulaic way. Their self-assessment of the piece of work they are commenting upon draws on given criteria of which they are very much aware but from which they are detached. They do not draw on any personal measure of quality based on the composition's creative aspects and their involvement in the process. Quality is judged in their minds by technical correctness and compliance. None of this is wrong in itself, but arguably a more comprehensive and complete understanding of writing with its purposes and satisfactions is missing.

\section{Creative Discourse}

Question B1 was unusual in the survey. The child seems to be making an important link between writing and thinking in a similar way to how Bereiter and Scardamalia (1993) describe the process of knowledge transforming. Writing contributes to the child's understanding of experience by becoming part of thought. Question B2 makes reference to the content of the work and B3 makes the point about the inspiration for the piece which also suggests the child's understanding of how other texts can contribute to the richness of their own meaning-making. Writing for these children goes beyond technical accuracy, presentation and execution as they appear still to show an awareness of the personal reasons to write and the communicative, intellectual and aesthetic outcomes of the endeavour which seem lost to many of the other children.

\section{Compliance Discourse}

$16.4 \%$ of answers I have categorised as being part of a compliance discourse. The children who responded with this discourse were proud of their work because they received praise from their teachers. As one might expect, children enjoy having their work praised. Hard work at achieving the given task made the children proud of their endeavours. My purpose here is not to condemn this form of response, but to highlight it as being one of a range of discourses that contribute to a possible imbalance in how children perceive writing and their contribution of writing within the context of the school.

\section{Question C: Skills Discourse}

In answer to Question C there is emphasis on the transcriptional/technical and the skills base of writing. The acronym V.C.O.P. - Vocabulary, Connectives, Openers, Punctuation - was used by children in a number of their answers. This is an acronym that derives from a writing programme devised by Ros Wilson (2003). Advice to parents published by a cluster of schools unconnected to the schools in this study typically describes the use of the acronym as a means 'to help children understand the key aspects of writing and how they can progress to the next level of writing...' It 'works on the principle of exploring where aspects of writing can be improved or 'up-levelled' (Meldrum Cluster 
Schools 2014). 'Up-levelled' refers to moving from one National Curriculum sub-level in the current assessment criteria to the next. The children in our study were very familiar with V.C.O.P as a way to improve the quality of their work. It was intrinsic to the skills discourse.

I want to argue that the skills discourse is contributing to perceptions about writing in schools that in turn lead to children's alienation from writing. The children appear to be driven by the formula to which they adhere, to the extent that the real-life purposes of writing become divorced from the exercise of writing in school. In many cases they have no control of the form, content, purpose or product of their labours. The children are denied the potential real and meaningful purposes of their work. The children's writing, the product of their labours, has been made into a 'thing'; it has been objectified, and it no longer belongs to them.

\section{Creative Discourse}

Creative and imaginative content was favoured by a small percentage of respondents along with an understanding of the importance of reading other texts to provide inspiration and guidance. This was in contrast to the majority of children who emphasised the urgency to follow a formula or to reach set targets. One could argue that these answers reflect the respondents' concern to please the reader by the author's offering something of themselves through their imagination and their understanding of high-quality engaging compositions.

\section{Compliance Discourse}

The children once again emphasised the importance of a determination to complete the exercise set. Here too they highlight an alienated approach to their writing - hard graft, concentration and resilience. In reflecting on the imbalance of perspectives, Ivanic's (2004) belief is that a skills discourse (which I see as being linked to a compliance discourse) is foregrounded in times of 'moral panic' by those involved in education and education policy and is often related to standards and 'the state of the nation'. It also happens to be the discourse, Ivanic argues, that 'politicians, journalists and some researchers and teachers strongly' defend 'as the most important element, or even as the only significant element, in early or basic literacy education' (2004:228). In our discussions with teachers, they were keenly aware of pressures from the government of the time to emphasise a skills based literacy curriculum which help to explain the discourses being used. In this environment, as Gee contends (2001), discourses can be acquired by those who inhabit it, or they can be explicitly taught by those in power.

\section{Conclusions}

Exploring what children say about writing, utilising Ivanič's (2004) framework as a heuristic, provides a unique lens that has sought an ideological thread from the analysis. This study appears to show the development of a learned or 
acquired discourse by the children, demonstrated here by their ready use of the vocabulary offered by their teachers, for example, 'good verbs' or 'uplevelled'. Part of discourse is the vocabulary available to express that discourse and its underlying ideology. This is learned or acquired through a process which introduces and uses the terminology regularly. As part of the writing project described in this article, the university team shared and discussed the data generated from the survey with the teachers. They were in no doubt that the children were engaging in skills and compliance discourses because, above all else, they themselves used a skills and compliance discourse while teaching. The teachers arguably felt alienated from their own work, as they felt constraints upon what they were expected to do in classrooms. They sought a balance of discourses.

The teachers believed that they were being encouraged to present a formula for writing which was most likely to enable the children to succeed in formal assessments. By asking questions and listening to how children perceived writing in the writing project, the teachers were able to confront the dominant writing discourses. They explored the ideological perceptions of the children and this affected and galvanised their determination to change it. They worked together to look for the means to demonstrate how writing can be made meaningful to them; for example, they offered more choice and opportunities for children's writing independence. They introduced oral storytelling to emphasise composition of narratives away from the written word and enriched their use of drama to stimulate writing.

It seems evident from this study that a skills and compliance discourse was prevalent in children's views about writing. The ideology of writing in school and the child's place and identity as a literacy learner is built by these discourses, making writing arguably an alienated act and a technical exercise. For the children in this study, writing at school appears as a means to present oneself as a writer, above all else, 'correctly'. Indeed, accuracy and correctness override many other considerations for the use of the written word. Their writing has arguably been objectified and the children alienated from writing. This may lead one to conclude that the children are being prepared for something other than being accomplished writers in their own terms, producing writing for their own benefits and satisfactions.

\section{References}

Apple, M. W. (2004) Ideology and Curriculum. $3^{\text {rd }}$ Edition. London: Routledge. Baker, Sally (2011). Students' writing and the transitions from school to university: hybrid 'discourse of writing' positions of students and teachers. The 1st International Australasian Conference on Enabling Access to Higher Education, 5 - 7 December 2011, Adelaide, Australia.

Bearne, E., Graham, L and Marsh, J. (2007) Classroom Action Research in Literacy: a Guide to Practice. Royston: UKLA. 
Benton, M. and Fox, G. (1985) Teaching Literature: Nine to Fourteen. Oxford: Oxford University Press.

Berreiter, C. and Scardamalia, M. (1993) 'Composing and Writing' in R. Beard (ed.) Teaching Literacy: Balancing Perspectives. Abingdon: Hodder and Stoughton.

Britton, J. (1970) Language and Learning. Harmondsworth: Penguin.

Creswell, J. W. (2012) Educational Research: Planning, Conducting, and Evaluating Quantitative and Qualitative Research $4^{\text {th }}$ Edition. Boston MA: Pearson Education Inc.

Davis, J. M. (1998) 'Understanding the meanings of children: a reflexive process.' Children \& Society. Volume 12, Issue 5, p. 325-335.

Dixon, J. (1967) Growth through English. London: Oxford University Press.

Dombey, H. (2013) Writing: What the Evidence Says. Leicester: United Kingdom Literacy Association.

Elbow, P. (1973) Writing without Teachers. London: Oxford University Press. Fairclough, N. (2001) Language and Power. $2^{\text {nd }}$ Edition. Harlow: Pearson Education Limited.

Gavey, N. (1989) 'Feminist Postructuralism and Discourse analysis.' Psychology of Woman Quarterly, 13, 459-475.

Gee, J. P. (2001) 'What is Literacy?' in P. Shannon (ed.) Becoming Political, Too: New Readings and Writings on the Politics of Language Education Portsmouth, NH: Heinemann.

Grainger, T., Goouch, K and Lambirth, A. (2003) 'Playing the Game Called Writing: Children's Views and Voices'. English in Education, 37(2), p.4 - 15.

Grainger, T., Goouch, K. and Lambirth, A. (2005) Creativity and writing: developing voice and verve in the classroom. London: Routledge.

Graves, D. (1983) Writing: Teachers and Children at Work. London: Heinemann Educational.

Ivanič, R. (2004) 'Discourses of Writing and Learning to Write.' Language and Education, 18(3), 220-245.

Knapp, M.S. and Associates (1995) Teaching for Meaning in High-Poverty Classrooms. New York: Teachers' College Press.

Louden, W., Rohl, M., Barrat-Pugh, C., Brown, C., Cairney, T., Elederfield, J., House, H., Meiers, M., Rivaland, J. and Rowe, K.J. (2005). 'In teachers' hands: effective literacy teaching practices in the early years of schooling.' Australian Journal of Language and Literacy, 28(3), pp. 173-252 (Whole issue).

Lundgren, B. (2013) 'Bridging discourses in a writing classroom.' Education Inquiry Vol. 4, No. 2, pp. 315-332.

Medwell, J., Wray, D, Poulson, L. and Fox, R. (1998) Effective Teachers of Literacy. Exeter: University of Exeter for the Teacher Training Agency.

Meldrum Cluster Schools (2013) Parents' Guide to V.C.O.P.: Helping my child with V.C.O.P at home. http://www.methlick.aberdeenshire.sch.uk/ Parents_Guide_to_VCO \%5B1\%5D.pdf (accessed 02.10.2014).

McCarthey, S. J., Woodard, R. and Kang, G. (2013) 'Elementary Teachers Negotiating Discourses in Writing Instruction.' Written Communication 1-33. 
Morrow, V (2001) 'Using qualitative methods to elicit young people's perspectives on their environments: some ideas for community health initiatives.' Heath Education Research, 16(3), 255-268.

National Writing Project (1990) Perceptions of Writing. Edinburgh. Nelson. Wilkinson, I. and Townsend, M. (2000) 'From Rata to Rimu: grouping for instruction in best practice New Zealand classrooms.' The Reading Teacher, 53(6), pp. 460-471.

Williams, R. (1976) 'Base and Superstructure in Marxist Cultural Theory' in R. Dale, G. Esland and M. MacDonald (eds) Schooling and Capitalism: A Sociological Reader: London: Routledge \& Kegan Paul.

Wilson, R. (2003) Strategies for Immediate Impact on Writing Standards: Raising Standards in Writing. London: Andrell Education Ltd.

Wray, D. (1993) 'What do children think about writing?' Educational Review, vol. 45 , Issue 1 . 